Annals of Tropical Research 30[1]:137-146 (2008)

(c) VSU, Leyte, Philippines

\title{
Research Note: \\ Stream water quality of a Community-Based Forest Management (CBFM)-protected watershed in Baybay, Leyte, Philippines
}

\author{
Arturo E. Pasa \\ College of Forestry and Natural Resources, Visayas State University, Visca, \\ Baybay City, Leyte, 6521-A Philippines
}

\begin{abstract}
The study assessed the quality of stream water of the watershed within the Community-Based Forest Management (CBFM) Project in Cienda, Gabas, Baybay, Leyte, Philippines. Results showed that, on the average, streamflow velocity was $0.30 \mathrm{~m} / \mathrm{sec}$, streamflow volume $0.32 \mathrm{~m}^{3} / \mathrm{sec}$, turbidity $2.96 \mathrm{ntu}$ and the associated sediments $16.0 \mathrm{mg} /$ L. Odor and taste were unobjectionable. $\mathrm{pH}$ ranged from 7.50 to 7.0 while total hardness from 7.84 to $15.16 \mathrm{mg} / \mathrm{L}$. The average nitrite $\left(\mathrm{NO}_{2}\right)$ content was $11.115 \mathrm{mg} / \mathrm{L}$ while nitrate $\left(\mathrm{NO}_{3}\right)$ was $1.05 \mathrm{mg} / \mathrm{L}$. The concentration of nutrients was also very low. Phosphorous (P) ranged only from 2.20 to $4.46 \mathrm{mg} / \mathrm{kg}$ or parts per million (ppm) while potassium (K) ranged from 3.71 to $3.90 \mathrm{ppm}$. Sodium $(\mathrm{Na})$, calcium $(\mathrm{Ca})$, and magnesium $(\mathrm{Mg})$ concentrations were also very low. Heavy metals were detected but also at low concentrations.
\end{abstract}

Keywords: climate change communication, content analysis, news media, global warming, Philippine media

Correspondence: A. Pasa. Address: College of Forestry and Natural Resources, Visayas State University, Visca, Baybay City, Leyte, 6521-A Philippines Tel. No. (053)335-4210

DOI: 10.32945/atr30110.2008 


\section{INTRODUCTION}

Water is central to many national concerns, including energy, food production, environmental quality and regional economic development. Yet, most people continue to use water with little concern for the prescribed perils (Dzurik, 2003). Lean et al. (1990) reported that surface waters are being polluted with a frightening assortment of municipal, industrial and agricultural wastes. Even in industrialized countries, where water quality legislation has taken hold, pollution is still a nagging problem. For much of the developing world, rivers and lakes are often clogged with a virulent mixture of industrial toxins, untreated sewage, and agricultural chemicals.

Lean et al. (1990) cited the findings from the World Resources Institute (1988-1989) that nitrates in drinking water may cause blood poisoning in infants, hypertension in children, gastric cancer in adults, and fetal malformations. The combination of high nitrates with pesticides is carcinogenic (cancer-forming) and mutagenic (causing birth defects). The high concentration of nutrients in rivers or lakes is known to cause the abnormal growth of aquatic plants that will deplete the amount of oxygen present causing aquatic animals die. High nutrient concentration will also cause periodic outbreak of toxic blue-green algal blooms (Encarta, 2005).

Agenda 21 stated that nearly half of the world's population is affected in various ways by the degradation of watershed areas (FAO, 2006) and one of which is obviously potable water supply. Watersheds which are common sources of water for various societies on earth are the sites for settlements, agricultural production, industrial centers and commercial complex. In the coming years, if unabated, these areas will no longer provide the potable water for the diverse users in view of the relentless degrading land uses by various entities. The world's supply of freshwater therefore depends largely on people's capacity to manage upstream-downstream flows (FAO, 2006).

Philippine watersheds also suffer similar anthropogenic pressures as manifested by the Ormoc flashfloods, Quezon Province disaster, and Southern Leyte tragedy. At present, only an estimated 0.80 million ha of old growth dipterocarp forest remain (Rebugio et al., 2005) due to commercial logging and land use conversions. To enhance watershed protection, local communities were given the noble task of protecting the uplands and conserving the resources 
therein through the Community-Based Forest Management (CBFM) scheme. Thus this study was conducted to obtain baseline information on stream water quality under the CBFM scheme of protecting the remaining watersheds. Hence, data generated from this study is anticipated to provide valuable information for policy formulation involving smallholders, watersheds and water quality.

\section{RESEARCHMETHODS}

\section{Site of the study}

The study site was the west-oriented watershed within the 2236 ha Community-Based Forest Management (CBFM) in Cienda, Gabas, Baybay, Leyte, Philippines. The site is rugged and mountainous with slope ranging from 30 to 80 percent and lies between 124 $4^{\circ} 0^{\prime}$ longitude and $10^{\circ} 44^{\prime}$ latitude having a Type IV climate characterized by a more or less even distribution of rainfall throughout the year (Figure 1). On average, June to January months are wet months while February to May are relatively dry. Average annual rainfall is $2500 \mathrm{~mm}$ while the average annual minimum and maximum temperatures are $22.3^{\circ} \mathrm{C}$ and $33.67^{\circ} \mathrm{C}$, respectively (PAGASA 2007). The monthly average wind velocity is $2.17 \mathrm{~m}$ per second with the highest occurring during February to March and July that is attributed to the northeast and southeast monsoon (CRMF, 2002).

Sampling site 1 (upper portion) was within the protected zone, the second sampling site (middle portion) within the buffer zone, and the third sampling site (lower portion) within the multiple-use zone. The protected zone, located in the northeast portion of the CBFM project site, is a wilderness area protected against human interventions. The buffer zone, located immediately below the protected zone along the southwest orientation, is the portion of the project site where regulated use is permitted. The multiple-use zone is the lower most portion of the project site where traditional cultivation like abaca and coconut plantations is found. 


\section{Field and laboratory methods}

Water samples were collected, employing stratified sampling technique, at strategic locations within the river system of the study site (Figure 1) using sterilized plastic bottles. Samples were immediately brought and analyzed for the associated nutrients, sediments, hardness, turbidity, and heavy metals at the Central Analytical Service Laboratory of the Visayas State University, Baybay, Leyte. Sample collections for physico-chemical properties were replicated three times while streamflow discharge and velocity were determined seven times within the study period from June to November 2005.

\section{RESULTS AND DISCUSSION}

The average streamflow velocity in the watershed was $0.303 \mathrm{~m} / \mathrm{sec}$ (range: 0.230 to $0.344 \mathrm{~m} / \mathrm{sec}$ ) while the average streamflow volume was $0.318 \mathrm{~m}^{3} /$ $\mathrm{sec}$. Site 3 as the lowermost sampling location is the point of convergence of all water from upper and middle sampling sites, thus having the highest volume. Turbidity values varied from 2.65 to 3.26 ntu with site 3 as the least turbid. Based on WHO (1993), the turbidity of water in the watershed is still within the acceptable maximum limit of 5 NTU. The associated sediments on streamflow was very minimal ranging only from 11.0 to $21.0 \mathrm{mg} / \mathrm{L}$ (Table 1) which was lower compared with the maximum limit set under DAO34-S 1990 of $25 \mathrm{mg} / \mathrm{L}$ (Appendix Table 1).

Odor and taste of water within the three sampling sites were unobjectionable while $\mathrm{pH}$ readings varied from 7.50 to 7.61 but still falling within the allowable range for class AA waters based from DAO 34 (S 1990) and WHO (1993). This means that the stream water within the CBFM project area is in superior condition in terms of odor, taste and $\mathrm{pH}$. Contrary to the $\mathrm{pH}$ value of soil (i.e. 5.10-6.57), the $\mathrm{pH}$ of the stream water within the study site was higher. This condition could be due to basaltic geochemistry of the parent material of the site as reported by Asio (1996) as well as to the absence of sources of pollutants like factories, mining operations, and other possible contributory agents of acidity.

Total hardness ranged from 7.843 to $15.164 \mathrm{mg} / \mathrm{L}$ which are lower than the standard limit set by WHO (1993). Too hard water, which is caused 


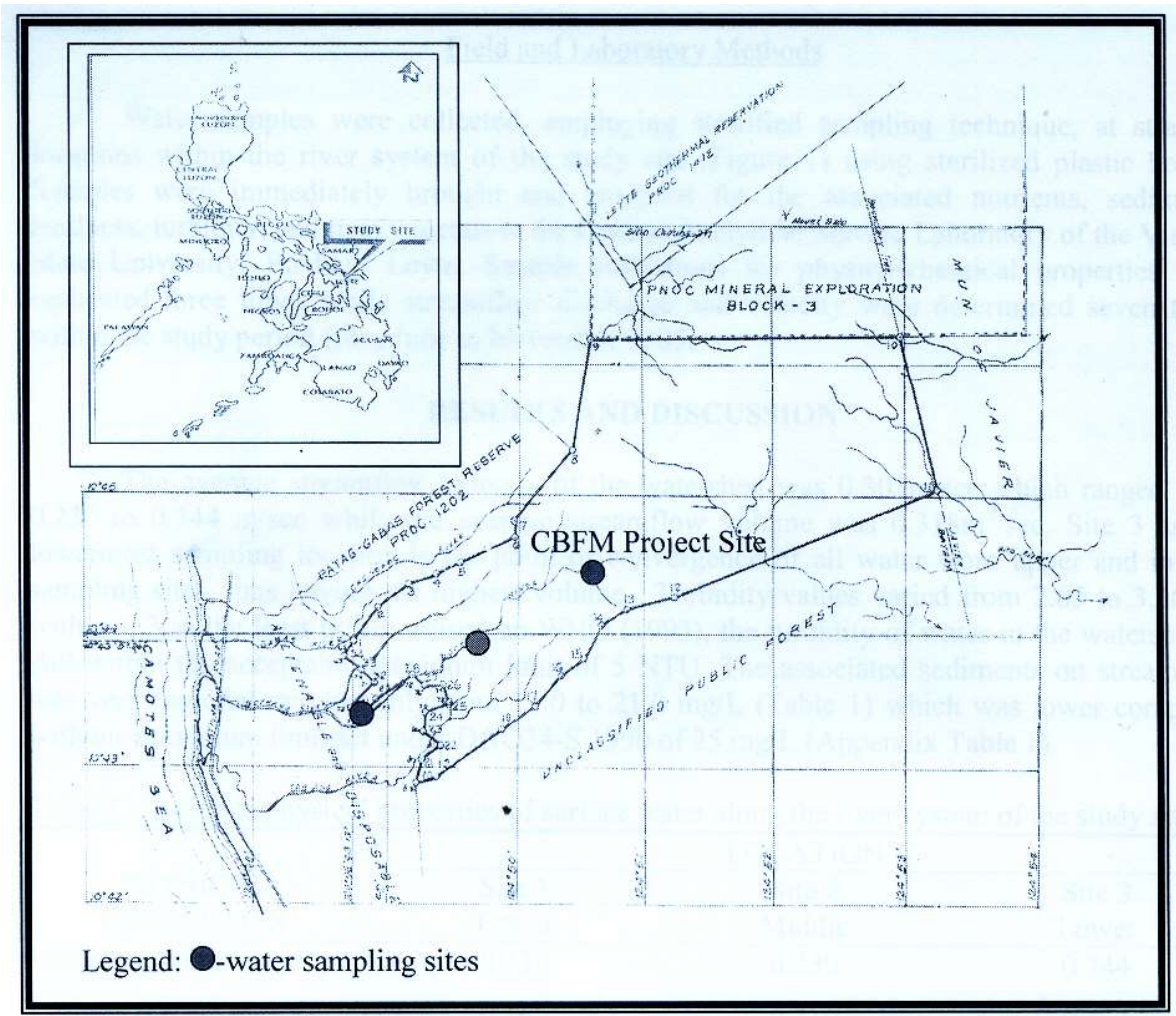

Fig. 1. Map showing the location of the study site within the CBFM Project 
Table 1. Average physical properties of stream water of the study site

\begin{tabular}{llll}
\hline Physical properties & \multicolumn{3}{c}{ Location } \\
\cline { 2 - 4 } & $\begin{array}{l}\text { Site 1 } \\
\text { Upper }\end{array}$ & $\begin{array}{l}\text { Site 2 } \\
\text { Middle }\end{array}$ & $\begin{array}{l}\text { Site 3 } \\
\text { Lower }\end{array}$ \\
\hline Velocity $(\mathrm{m} / \mathrm{sec})$ & 0.336 & 0.230 & 0.344 \\
Volume $\left(\mathrm{Q}=\mathrm{m}^{3} / \mathrm{sec}\right)$ & 0.162 & 0.319 & 0.474 \\
Turbidity $(\mathrm{NTU})$ & 3.260 & 3.250 & 2.650 \\
Sediments $(\mathrm{mg} / \mathrm{L})$ & 21.00 & 12.00 & 11.00 \\
& & & \\
\hline
\end{tabular}

Table 2. Average chemical properties of surface water along the river system of the study site

\begin{tabular}{llll}
\hline \multirow{2}{*}{ CHEMICALPROPERTIES } & \multicolumn{3}{c}{ Location } \\
\cline { 2 - 4 } & $\begin{array}{l}\text { Site 1 } \\
\text { Upper }\end{array}$ & $\begin{array}{l}\text { Site } 2 \\
\text { Middle }\end{array}$ & Site 3 \\
& Unobjectionable & Unobjectionable & Unobjectionable \\
\hline \multirow{2}{*}{ Odor } & Unobjectionable & Unobjectionable & Unobjectionable \\
Taste & 7.510 & 7.504 & 7.610 \\
pH & 7.843 & 8.172 & 15.164 \\
Total Hardness $(\mathrm{mg} / \mathrm{L})$ & 7.740 & 6.906 & 15.321 \\
$\mathrm{NO}(\mathrm{ug} / \mathrm{L})$ & 1.282 & 1.696 & 0.820 \\
$\mathrm{NO}(\mathrm{mg} / \mathrm{L})$ & 3.120 & 2.200 & 4.460 \\
Total $\mathrm{P}(\mathrm{ppm})$ & 3.904 & 3.708 & 3.884 \\
Total K $(\mathrm{ppm})$ & 4.753 & 3.969 & 4.902 \\
Total $\mathrm{Na}(\mathrm{ppm})$ & 5.138 & 5.944 & 4.894 \\
Total Ca $(\mathrm{ppm})$ & 2.057 & 1.545 & 1.879 \\
Total $\mathrm{Mg}(\mathrm{ppm})$ & & & \\
& & &
\end{tabular}

Table 3. Average concentration of heavy metals within the river system of the study site

\begin{tabular}{llll}
\hline Heavy Metals & \multicolumn{3}{c}{ Location } \\
\cline { 2 - 4 } & $\begin{array}{l}\text { Site 1 } \\
\text { Upper }\end{array}$ & $\begin{array}{l}\text { Site 2 } \\
\text { Middle }\end{array}$ & $\begin{array}{l}\text { Site 3 } \\
\text { Lower }\end{array}$ \\
\hline Total Cd (ppm) & 0.003 & 0.004 & 0.006 \\
Total Cu (ppm) & 0.058 & 0.026 & 0.029 \\
Total Zn (ppm) & 0.088 & 0.077 & 0.079 \\
Total Ni (ppm) & nil & 0.002 & 0.001 \\
\hline
\end{tabular}


largely by calcium and magnesium salts, is undesirable as it could lead to human disorders. The study however showed that hardness of water within the site is still tolerable. The nitrite $\left(\mathrm{NO}_{2}\right)$ content varied from 6.906 to $15.32 \mathrm{mg}$ / L while nitrate $\left(\mathrm{NO}_{3}\right)$ ranged only from 0.82 to $1.28 \mathrm{mg} / \mathrm{L}$ all of which were below the WHO (1993) maximum levels, implying that the water in the site is of good quality.

The concentration of nutrients of the stream water was also very low. Phosphorous $(\mathrm{P})$ ranged only from 2.20 to $4.46 \mathrm{ppm}$ while potassium $(\mathrm{K})$ varied from 3.71 to $3.90 \mathrm{ppm}$. Sodium $(\mathrm{Na})$, calcium $(\mathrm{Ca})$, and magnesium $(\mathrm{Mg})$ concentrations were also very low (Table 2). This indicates the good quality of water in terms of nutrient level along the site's river system. As mentioned earlier, the hardness of water was also very low, implying the low concentration of nutrients mentioned above

Cadmium $(\mathrm{Cd})$ content of water ranged from 0.003 to $0.006 \mathrm{mg} / \mathrm{L}$ which is within the acceptable level set under DAO 34-S 1990. High Cd can cause diarrhea as well as liver and kidney disorder (Encarta, 2005), hence its high concentration in water is undesirable. In addition, there were lower concentrations of copper $(\mathrm{Cu})$, zinc $(\mathrm{Zn})$, and nickel $(\mathrm{Ni})$. Cu content varied only from 0.026 to $0.058 \mathrm{mg} / \mathrm{L}$ while $\mathrm{Zn}$ ranged from 0.077 to 0.088 and $\mathrm{Ni}$ from 0.00 to $0.002 \mathrm{mg} / \mathrm{L}$. The quantitative analyses of the three heavy metals showed that their concentrations were far below the limit set under DAO 34S 1990 and WHO 1993 and 2004 at $1.00 \mathrm{mg} / \mathrm{L}$ for $\mathrm{Cu}$ and $\mathrm{Zn}$, and $0.02 \mathrm{mg} /$ L for Ni, respectively (Table 3 ).

\section{CONCLUSION AND POLICY IMPLICATIONS}

The stream water of the study site was indeed of good quality. The physicochemical properties and naturally occurring heavy metals of surface water are within the acceptable range of the WHO $(1993,2004)$ and DAO 34 S1990. Therefore, algal bloom and heavy metal toxicity are not a threat to the local people dependent on water from the watershed. This was made possible through the relentless effort of the community protecting the watershed against illegal logging and river poisoning. In fact, they were able to apprehend about 18 cases of illegal logging activities and dozens of river poisoning. Hence the 
said project was nominated as one of the "exemplary forest management in Asia and the Pacific" (see RAP Publication 2005/02). However, sustaining the enthusiasm of smallholders to keep protecting the watershed remains a great challenge. It is suggested that the government would consider rewards or livelihood opportunities for smallholders in relation to watershed protection. The government may also consider the emerging opportunities on this aspect in view of the global political commitment of halving poverty by 2015 and the Payment for Environmental Services (PES) program.

Rewarding " or as commonly known in South America " payment for environmental services (PES) is a newly emerging initiative in forestry and agroforestry development programs. For example, the program for 'Rewarding the Upland Poor for their Environmental Services (RUPES)' explores new ways of addressing poverty (Van Noordwijk 2007). The goal of the program is to enhance livelihood and resource security for the upland poor in Asia, and maintain or enhance environmental functions (De los Angeles 2007). Opportunities exist for local farmers to maintain or restore local agro-ecosystem functions that protect watersheds, conserve biodiversity and sequester carbon. These include financial incentives and resource security that promote conservation. In addition, new market mechanisms that have the potential to reward the upland poor communities for effective and sustainable natural resources management, are emerging. These opportunities are supported by the global political commitment of halving poverty by 2015 (RUPES 2002). Similar topic is currently reviewed by FAO (2006).

\section{ACKNOWLEDGMENT}

The author is grateful to the Southeast Asian Regional Center for Graduate Study and Research in Agriculture (SEARCA), German Academic Exchange Service (DAAD) of the Federal Republic of Germany for the financial support, and the Commission on Higher Education (CHED) of the Republic of the Philippines for the dissertation grant. He is also indebted to Teodoro R. Villanueva, Wilfredo M. Carandang, Myrna G. Carandang, Juan M. Pulhin, Luz Asio and Cynthia Godoy for their technical assistance. Likewise, to the people's organization (CSVFA) for allowing the author to conduct research in their CBFM project. 


\section{LITERATURE CITED}

ASIO, V.B. 1996. Characteristics, weathering, formation, and degradation of soils from volcanic rocks in Leyte, Philippines. Hohenheimer Bodenkundliche Hefte 33, Stuttgart, Germany

CRMF, 2002. Community-based forest management project profile. Cienda-San Vicente Farmers Association, Cienda, Gabas, Baybay, Leyte.

DE LOS ANGELES, M. 2007. Personal communication, Environmental Economic Consultant, World Bank Institute, Washington DC.

DENR Administrative Order 34 S 1990. Revised water usage and classification. Water quality criteria amending section numbers $68-69$, chapter III of the NPCC rules and regulations. Visayas Avenue, Diliman, Quezon City.

DZURIK, A.A. 2003. Water resources planning. Rowman and Littlefield Publishers, Inc.

ENCARTA ENCYCLOPEDIA, 2005. Heavy metals in water. All rights reserved.

FAO, 2006. Better Forestry, Less Poverty: a practitioners guide. FAO Forestry Paper 149. Viale delle Terme di Caracalla, 00100 Rome, Italy.

FAO, 2006. The new generation of watershed management programmes and projects. FAO Forestry Paper 150. Viale delle Terme di Caracalla, 00100 Rome, Italy.

LEAN, G., D. HINRICHSEN and A. MARKHAM. (1990), WWF Atlas of the Environment, Prentice Hall, New York.

PAGASA (Philippine Atmospheric, Geophysical and Astronomical Service Administration) Agrometeorology Station). 2007. Average annual rainfall and temperature in midwestern Leyte. Visayas State University, Baybay, Leyte.

RAP Publication. 2005. In Search of Excellence: Exemplary Forest Management in Asia and the Pacific. P. Durst, C. Brown, H.D. Tacio and M. Ishikawa Eds. AsiaPacific Forestry Commission. FAO regional Office for Asia and the Pacific, Bangkok.

REBUGIO, L.L., et al. 2005. Forest Restoration in the Philippines: A Review for Research and Development Initiatives. Los Banos: College of Forestry and Natural Resources, UPLB. ASEAN-KOREAEnvironmental Cooperation Project.

RUPES. 2002. Primer on Developing Mechanisms for Rewarding the Upland Poor in Asia for Environmental Services They Provide. World Agroforestry Centre, Los Baños, Laguna, the Philippines. 
VAN NOORDWIJK, M. 2007. Personal communication, ICRAF Regional Coordinator for Southeast Asia, Bogor, Indonesia.

WORLD HEALTH ORGANIZATION. 1993. Revised guidelines for drinking water quality (184). Geneva, Switzerland.

WORLD HEALTH ORGANIZATION. 2004. Guidelines for drinking water quality. Third Edition. Geneva, Switzerland.

Appendix Table 1. Standard quality criteria for water resources

\begin{tabular}{lll}
\hline Parameters & Standard Range & References \\
\hline Water Resource & & \\
$\mathrm{pH}$ & $6.5-8.5$ & WHO, 1993 \\
Odor & Objectionable/Unobjectionable \\
Taste & Objectionable/Unobjectionable \\
Turbidity & $5 \mathrm{NTU}$ & WHO, 1993 \\
Sediments & $25 \mathrm{mg} / \mathrm{L}(\mathrm{TSS})$ & DAO 34-S 1990 \\
Total Hardness & $300 \mathrm{mg} / \mathrm{L}(\mathrm{CaCO} 3)$ & WHO, 1993 \\
NO2 $($ Nitrite) & $3 \mathrm{mg} / \mathrm{L}$ & WHO, 1993 \\
NO3 $(\mathrm{Nitrate})$ & $50 \mathrm{mg} / \mathrm{L}$ & WHO, 1993 \\
Total Cd & $0.010 \mathrm{mg} / \mathrm{L}-0.003 \mathrm{mg} / \mathrm{L}$ & DAO 34-S 1990,WHO 1993 \\
Total Cu & $1.00 \mathrm{mg} / \mathrm{L}$ & DAO 34-S 1990,WHO 1993 \\
Total Zn & $1.00 \mathrm{mg} / \mathrm{L}$ & WHO, 1993 \\
Total Ni & $0.02 \mathrm{mg} / \mathrm{L}$ & WHO, 2004 \\
\hline
\end{tabular}

